\title{
Biphasic $\mathrm{Ca}^{2+-}$ dependent switching in a calmodulin-IQ domain complex ${ }^{\dagger}$
}

\author{
D. J. Black, Jared Leonard, and Anthony Persechini \\ Division of Molecular Biology and Biochemistry, University of Missouri-Kansas City, Kansas City, \\ Missouri 64110-2499
}

\begin{abstract}
The relationship between the free $\mathrm{Ca}^{2+}$ concentration and the apparent dissociation constant for the complex between calmodulin $(\mathrm{CaM})$ and the neuromodulin IQ domain consists of two phases. In the first phase $\mathrm{Ca}^{2+}$ bound to the C-ter $\mathrm{EF}$ hand pair in CaM increases the $\mathrm{K}_{\mathrm{d}}$ for the complex from the $\mathrm{Ca}^{2+}$-free value of $2.3 \pm 0.1 \mu \mathrm{M}$ to a value of $14.4 \pm 1.3 \mu \mathrm{M}$. In the second phase $\mathrm{Ca}^{2+}$ bound to the $\mathrm{N}$ ter EF hand pair reduces the $\mathrm{K}_{\mathrm{d}}$ for the complex to a value of $2.5 \pm 0.1 \mu \mathrm{M}$, reversing the effect of the first phase. Due to energy coupling effects associated with these phases the mean dissociation constant for $\mathrm{Ca}^{2+}$-binding to the $\mathrm{C}$-ter $\mathrm{EF}$ hand pair is increased $\sim 3$-fold, from $1.8 \pm 0.1$ to $5.1 \pm 0.7$ $\mu \mathrm{M}$, and the mean dissociation constant for $\mathrm{Ca}^{2+}$-binding to the $\mathrm{N}$-ter EF hand pair is decreased by the same factor, from $11.2 \pm 1.0$ to $3.5 \pm 0.6 \mu \mathrm{M}$. These characteristics produce a bell-shaped relationship between the apparent dissociation constant for the complex and the free $\mathrm{Ca}^{2+}$ concentration, with a distance of 5-6 $\mu \mathrm{M}$ between the midpoints of the rising and falling phases. Release of CaM from the neuromodulin IQ domain therefore appears to be promoted over a relatively narrow range of free $\mathrm{Ca}^{2+}$ concentrations. Our results demonstrate that CaM-IQ domain complexes can function as a biphasic $\mathrm{Ca}^{2+}$ switches through opposing effects of $\mathrm{Ca}^{2+}$ bound sequentially to the two EF hand pairs in CaM.
\end{abstract}

The $\mathrm{Ca}^{2+}$-binding protein calmodulin $(\mathrm{CaM})$ plays a central role in transducing $\mathrm{Ca}^{2+}$ signals through its interactions with more than 30 different target proteins. Many of these, such as phosphodiesterase, myosin light chain kinase and the constitutive nitric oxide synthases do not interact significantly with $\mathrm{Ca}^{2+}$-free $\mathrm{CaM}$ (apoCaM) (1-4). However, a large class of targets bind apoCaM at least as well as the $\mathrm{Ca}^{2+}$-liganded forms of the protein. The majority of these, including neuromodulin, neurogranin, the unconventional myosins and some $\mathrm{Ca}^{2+}, \mathrm{K}^{+}$and $\mathrm{Na}^{+}$channels interact with CaM via IQ domains, which have the consensus sequence: [I,L,V] QxxxR[G,x] xxx[R,K] $(5,6)$. These regions bind apoCaM and/or $\mathrm{Ca}^{2+}$-liganded $\mathrm{CaM}$ with dissociation constants ranging from subnanomolar to micromolar, depending upon their precise sequence and context (6). CaM-IQ domain complexes have been implicated in a variety of regulatory processes, including positive and negative regulation of ion channels and unconventional myosin based motility (6). Some IQ domain proteins have been proposed to function as local intracellular stores of CaM (7).

The potential importance of such stores has been heightened by recent investigations indicating that the intracellular CaM concentration is limiting: We have found that a dephosphorylationdependent increase in the amount of $\mathrm{CaM}$ bound to nitric oxide synthase in endothelial cells significantly reduces the available $\mathrm{CaM}$ concentration during a $\mathrm{Ca}^{2+}$ signal, and inhibits the

\footnotetext{
${ }^{\dagger}$ This work was supported by NIH Grant DK53863 to A.P.

$\ddagger$ To Whom All Correspondence Should be Addressed: Division of Molecular Biology and Biochemistry, University of Missouri-Kansas City, 5007 Rockhill Road, Kansas City, MO 64110-2499, Tel. 816-235-6076; Fax. 816-235-5595; Email: Persechinia@umkc.edu.
} 
activity of the plasma membrane $\mathrm{Ca}^{2+}$ pump and presumably other $\mathrm{CaM}$ targets (8). Rahkilin and coworkers have recently demonstrated that a limiting CaM concentration in neurons results in similar coupling among target activities (9). Finally, the work of Isotani and coworkers suggests that the CaM concentration is limiting in smooth muscle tissue (10). Thus, CaM and its targets can be considered to form what we have termed the CaM network (11). Although the available $\mathrm{CaM}$ concentration is a function of all its various interactions, proteins that function as $\mathrm{CaM}$ stores are of particular interest, as they are likely to contribute in important ways to the form and function of the CaM network. Neuromodulin, a neuronal IQ domain protein found in axons and terminals, is perhaps the best studied example of such a protein (7). Neurogranin, a smaller protein with an essentially identical IQ domain, is thought to perform a similar function in dendritic spines $(12,13)$.

In this paper we describe a steady-state mechanism for $\mathrm{Ca}^{2+}$-dependent switching in the neuromodulin CaM-IQ domain complex. A surprising aspect of this mechanism is its fundamentally biphasic nature: $\mathrm{Ca}^{2+}$ binding one $\mathrm{EF}$ hand pair in CaM decreases the affinity of the complex; binding to the other then completely reverses this effect. The result is a bellshaped relationship between the apparent dissociation constant for the complex and the free $\mathrm{Ca}^{2+}$ concentration.

\section{Materials and Methods}

\section{Proteins}

The cDNA encoding $\mathrm{BSCaM}_{\mathrm{IQ}}{ }^{1}$, a fluorescent reporter that binds CaM via an IQ domain sequence derived from neuromodulin, was assembled in a modified pET30a vector (Novagen, Inc.). The composition of $\mathrm{BSCaM}_{\mathrm{IQ}}$ is similar to that of other $\mathrm{CaM}$ biosensors we have developed $(14,15)$, except that it contains a form of enhanced yellow fluorescent protein $\left(\mathrm{EYFP}_{\mathrm{C}}\right)$ in which the $\mathrm{pK}_{\mathrm{a}}$ for fluorescence quenching is shifted from a value of $\sim 7$ to a value of $\sim 6$, which increases EYFP fluorescence emission under the conditions used in these investigations (16). The CaM-binding sequence bridging the ECFP and $\mathrm{EYFP}_{\mathrm{C}}$ variants in BSCaM $_{\mathrm{IQ}}$ : AAATKIQA]A]FRGHITRKKLKGEKKGAA, is based on the IQ domain region in neuromodulin (neuromodulin sequence underlined), differing only in the substitution of an Ala residue (in brackets) for a Ser. This corresponds with position 41 in the neuromodulin amino acid sequence (17). Phosphorylation at this position in full-length neuromodulin blocks CaM binding, but substitution of a Gly residue does not affect binding (17). We have also developed a bipartite fluorescent reporter system consisting of $\mathrm{EYFP}_{\mathrm{C}}$-neuromodulin and ECFP-CaM fusion proteins. In the neuromodulin fusion the fluorescent protein is joined to the $\mathrm{N}$-terminus of full-length native neuromodulin via a Gly-Thr amino acid pair. In the CaM fusion the fluorescent protein is joined to the N-terminus of native CaM via a GASGSAAAG polypeptide linker. All fluorescent protein constructs were expressed with amino-terminal 6His tags in BL21(DE3), and were purified using $\mathrm{Ni}^{+}$-chelate affinity chromatography as described previously (18). Both of these fluorescent reporter systems are represented schematically in Fig. 1.

\footnotetext{
${ }_{1}^{1}$ Abbreviations: BSCaMIQ, fluorescent biosensor containing a CaM-binding sequence based on the IQ domain in neuromodulin; ECFP, cyan emitting variant of green fluorescent protein, EYFPC $_{C}$, yellow emitting variant of green fluorescent protein that has been modified to reduce the dependence of its fluorescence emission on $\mathrm{pH}$ over the physiological range; $\mathrm{N}_{\mathrm{X}} \mathrm{CCaM}\left(\mathrm{N}_{\mathrm{X}} \mathrm{C}\right)$, mutant CaM with E31A and E67A substitutions; $\mathrm{NC}_{\mathrm{X}} \mathrm{CaM}\left(\mathrm{NC}_{\mathrm{X}}\right)$, mutant $\mathrm{CaM}$ with E104A and E140A substitutions; $\mathrm{N}_{2} \mathrm{CCaM}\left(\mathrm{N}_{2} \mathrm{C}\right), \mathrm{CaM}$ with $\mathrm{Ca}^{2+}$ bound to both $\mathrm{N}$-ter $\mathrm{EF}$ hands; $\mathrm{NC}_{2} \mathrm{CaM}\left(\mathrm{NC}_{2}\right), \mathrm{CaM}$ with $\mathrm{Ca}^{2+}$ bound to both $\mathrm{C}$-ter $\mathrm{EF}$ hands; $\mathrm{N}_{2} \mathrm{C}_{2} \mathrm{CaM}\left(\mathrm{N}_{2} \mathrm{C}_{2}\right), \mathrm{CaM}$ with $\mathrm{Ca}^{2+}$ bound to all four EF hands; $\mathrm{N}_{2} \mathrm{C}_{\mathrm{X}} \mathrm{CaM}\left(\mathrm{N}_{2} \mathrm{C}_{\mathrm{X}}\right)$ and $\mathrm{N}_{\mathrm{X}} \mathrm{C}_{2} \mathrm{CaM}\left(\mathrm{N}_{\mathrm{X}} \mathrm{C}_{2}\right)$; mutant $\mathrm{CaMs}$ with $\mathrm{Ca}^{2+}$ bound to the remaining functional EF hands; $\mathrm{K}_{1,2}$, the geometric mean of $\mathrm{K}_{1}$ and $\mathrm{K}_{2} ; \mathrm{K}_{3,4}$, the geometric mean of $\mathrm{K}_{3}$ and $\mathrm{K}_{4}$; BAPTA, 1,2-bis(2-aminophenoxy)ethane-N,N,N',N '-tetraacetic acid; dibromo-BAPTA, 1,2-bis(2-amino-5,5'-dibromophenoxy)ethane-N,N,N',N'-tetraacetic acid; FRET, fluorescence resonance energy transfer.
} 
Native and mutant CaMs were expressed and purified as described in detail elsewhere (19, $20)$. The two mutant CaMs used in these studies are $\mathrm{N}_{\mathrm{x}} \mathrm{CCaM}\left(\mathrm{N}_{\mathrm{x}} \mathrm{C}\right)$, in which glutamic acid residues at positions 31 and 67 in the N-ter EF-hands have been replaced by alanines, and $\mathrm{NC}_{\mathrm{X}} \mathrm{CaM}\left(\mathrm{NC}_{\mathrm{x}}\right)$, in which the homologous glutamic acid residues at positions 104 and 140 have been replaced. These mutations eliminate $\mathrm{Ca}^{2+}$ binding to the $\mathrm{N}$-ter or $\mathrm{C}$-ter $\mathrm{EF}$ hand pair, as indicated by the " $\mathrm{x}$ " subscript.

\section{Fluorescence measurements}

A Photon Technologies International (Monmouth Junction, NJ) QM-1 fluorometer operated in photon-counting mode was used for all steady-state fluorescence measurements. Monochromator excitation and emission slit widths were set to produce bandwidths of $\sim 2.5$ $\mathrm{nm}$. All experiments were performed at $23{ }^{\circ} \mathrm{C}$. The standard experimental buffer contained 25 $\mathrm{mM}$ Tris (pH 7.5), $0.1 \mathrm{M} \mathrm{KCl}, 100 \mu \mathrm{g} / \mathrm{ml} \mathrm{BSA}$, and other components as specified in the text or captions. For analysis of the $\mathrm{Ca}^{2+}$-dependencies of native and mutant $\mathrm{CaM}$ complexes, buffered free $\mathrm{Ca}^{2+}$ concentrations were produced using $1.5 \mathrm{mM}$ BAPTA, $1.5 \mathrm{mM}$ dibromoBAPTA and various amounts of added of $\mathrm{CaCl}_{2}$. Stated free $\mathrm{Ca}^{2+}$ concentrations were measured using $250 \mathrm{nM}$ indo-5F or mag indo- 1 according to established procedures (Molecular Probes, Inc.). As we have demonstrated elsewhere, there is no significant spillover in the fluorescence emissions of these $\mathrm{Ca}^{2+}$ indicator dyes and the $\mathrm{BSCaM}_{\mathrm{IQ}}$ reporter $(8,21)$.

When required, proteins and buffers were decalcified by successive treatments with Chelex ${ }^{\mathrm{TM}}$ and a BAPTA-polystyrene column (Molecular Probes, Inc.). Contaminating amounts of $\mathrm{Ca}^{2+}$ in protein solutions at their stated working concentrations were $150 \mathrm{nM}$ or less, based on the absence of any detectible effect on the $\mathrm{A}_{263}$ of dibromo-BAPTA.

\section{Analysis of fluorescence data}

Fractional changes in fluorescence were analyzed to extract apparent $\mathrm{K}_{\mathrm{d}}$ values for native or mutant CaMs using a standard hyperbolic binding equation, where FR is fractional response as defined in the relevant figure legends:

$$
\mathrm{FR}=[\mathrm{CaM}] /\left([\mathrm{CaM}]+K_{d}\right)
$$

A sequential $\mathrm{Ca}^{2+}$ binding model was used to analyze fractional changes in fluorescence due to $\mathrm{Ca}^{2+}$-dependent dissociation of the $\mathrm{N}_{\mathrm{x}} \mathrm{CCaM}$ or $\mathrm{NC}_{\mathrm{x}} \mathrm{CaM}$ complexes with $\mathrm{BSCaM}_{\mathrm{IQ}}$ :

$$
\mathrm{FR}=\frac{\left(\left[\mathrm{Ca}^{2+}\right]^{2} / \mathrm{K}_{1} \mathrm{~K}_{2}\right)}{\left(1+\left[\mathrm{Ca}^{2+}\right] / \mathrm{K}_{1}+\left[\mathrm{Ca}^{2+}\right]^{2} / K_{1} K_{2}\right)}
$$

where $K_{l}$ and $K_{2}$ in this case designate the apparent dissociation constants for the two sites in the functional $\mathrm{EF}$ hand pairs. A sequential mechanism for $\mathrm{Ca}^{2+}$ binding to the individual $\mathrm{EF}$ hands is assumed. This is supported by investigations in which $\mathrm{Ca}^{2+}$ binding to individual $\mathrm{EF}$ hands have been monitored spectrally (22-24). We have also assumed that dissociation requires occupancy of both sites in an EF hand pair. This may not be strictly correct, since NMR investigations indicate that occupancy of a single $\mathrm{Ca}^{2+}$-binding site can produce significant conformational changes in CaM (24). However, under steady-state conditions positive cooperativity between the sites in each EF hand pair restricts the amount of CaM with only one site occupied to negible levels (25).

\section{Direct determinations of $\mathrm{Ca}^{2+}$ binding constants}

Direct $\mathrm{Ca}^{2+}$-binding measurements were performed as described by Linse and coworkers $(26,27)$. In this approach $\mathrm{Ca}^{2+}$ binding to a BAPTA or dibromo-BAPTA chelator is measured based on its optical absorbance at $263 \mathrm{~nm}$ as known increments of $\mathrm{Ca}^{2+}$ are added to an initially decalcified solution containing the chelator and the $\mathrm{Ca}^{2+}$-binding protein of interest. The 
absolute amounts of free $\mathrm{Ca}^{2+}$ and $\mathrm{Ca}^{2+}$ bound to the chelator after each addition can thus be estimated, with the amount bound to the protein accounting for the remainder (28). We have found a 0.5 to 1 molar ratio of chelator to protein $\mathrm{Ca}^{2+}$-binding sites to yield the best determined $\mathrm{Ca}^{2+}$ dissociation constants. Apparent $\mathrm{Ca}^{2+}$ dissociation constants for proteins were derived from direct fits to observed chelator absorbance using the Caligator software package (28). A general four-site Adair equation was used to define $\mathrm{Ca}^{2+}$ binding to native CaM:

$\theta=\frac{1}{4}\left(\frac{K_{1}\left[\mathrm{Ca}^{2+}\right]+2 K_{1} K_{2}\left[\mathrm{Ca}^{2+}\right]^{2}+3 K_{1} K_{2} K_{3}\left[\mathrm{Ca}^{2+}\right]^{3}+4 K_{1} K_{2} K_{3} K_{4}\left[\mathrm{Ca}^{2+}\right]^{4}}{1+K_{1}\left[\mathrm{Ca}^{2+}\right]+K_{1} K_{2}\left[\mathrm{Ca}^{2+}\right]^{2}+K_{1} K_{2} K_{3}\left[\mathrm{Ca}^{2+}\right]^{3}+K_{1} K_{2} K_{3} K_{4}\left[\mathrm{Ca}^{2+}\right]^{4}}\right)$

where $\theta$ is the fractional saturation of the four sites in this protein. An abbreviated form of this expression was used to describe binding to the two CaM mutants, $\mathrm{NC}_{\mathrm{x}} \mathrm{CaM}$ and $\mathrm{N}_{\mathrm{x}} \mathrm{CCaM}$, which have only one functional $\mathrm{EF}$ hand pair:

$$
\theta=\frac{1}{2}\left(\frac{K_{1}\left[\mathrm{Ca}^{2+}\right]+2 K_{1} K_{2}\left[\mathrm{Ca}^{2+}\right]^{2}}{1+K_{1}\left[\mathrm{Ca}^{2+}\right]+K_{1} K_{2}\left[\mathrm{Ca}^{2+}\right]^{2}}\right)
$$

\section{Modeling}

The theoretical curves presented in Figs 8 and 9 were calculated using the Berkeley

Madonna software package (Macey and Oster, Inc). For this purpose an expanded version of the scheme presented in Fig. 7 was used in which $\mathrm{Ca}^{2+}$ binding to each EF hand pair is treated as a two-step sequential process. Since all simulations were allowed to reach a steady-state, only the ratios of the rate constants used for each step in the mechanism are important, and these are defined by the steady-state interaction parameters listed in Tables 1 and 2.

\section{Results}

\section{Binding of native and mutant $\mathrm{CaMs}$ to $\mathrm{BSCaM}_{\mathrm{IQ}}$ in the presence and absence of $\mathrm{Ca}^{2+}$}

The initial step in these investigations was to determine $\mathrm{K}_{\mathrm{d}}$ values for the complexes between the $\mathrm{BSCaM}_{\mathrm{IQ}}$ fluorescent reporter containing the neuromodulin IQ domain and apoCaM or $\left(\mathrm{Ca}^{2+}\right)_{4}$-CaM. Respective values of $2.3 \pm 0.1$ and $2.5 \pm 0.1 \mu \mathrm{M}$ were derived from the data presented in Fig. 2 (Table 1). Purified neuromodulin has previously been reported to bind apoCaM and $\left(\mathrm{Ca}^{2+}\right)_{4}-\mathrm{CaM}$ with $\mathrm{K}_{\mathrm{d}}$ values of 3.0 and $3.4 \mu \mathrm{M}$ under similar experimental conditions $(29,30)$. As seen in Fig. 2, at a free $\mathrm{Ca}^{2+}$ concentration of $10 \mu \mathrm{M}$ the apparent $\mathrm{K}_{\mathrm{d}}$ value for the $\mathrm{CaM}-\mathrm{BSCaM} \mathrm{IQ}_{\mathrm{Q}}$ complex increases to $10.8 \pm 1.1 \mu \mathrm{M}$, suggesting that the transition between the apoCaM and $\left(\mathrm{Ca}^{2+}\right)_{4}$-CaM complexes involves more weakly bound forms of CaM (Table 1).

To further investigate the basis for this apparent reduction in affinity at an intermediate free $\mathrm{Ca}^{2+}$ concentration we employed $\mathrm{N}_{\mathrm{x}} \mathrm{CCaM}$ and $\mathrm{NC}_{\mathrm{x}} \mathrm{CaM}$, mutants of $\mathrm{CaM}$ in which $\mathrm{Ca}^{2+}$ binding to the $\mathrm{N}$-ter or $\mathrm{C}$-ter EF hand pair has been abolished (19). These mutants provide a convenient way to isolate the effects of $\mathrm{Ca}^{2+}$ binding to each $\mathrm{EF}$ hand pair. Our results indicate that the properties of these mutant proteins are consistent with the properties of native CaM. Nevertheless, it should be borne in mind that the mutant EF hands in these proteins are likely to adopt conformations that differ from the corresponding native $\mathrm{Ca}^{2+}$-free conformations (31). As seen in Fig 3A, in the absence of $\mathrm{Ca}^{2+}$ both mutants bind the BSCaM $\mathrm{IQ}_{\text {Q }}$ reporter with a $\mathrm{K}_{\mathrm{d}}$ value of $\sim 2.3 \mu \mathrm{M}$, essentially identical to the value for native apoCaM (Table 1). In the presence of a saturating $\mathrm{Ca}^{2+}$ concentration the $\mathrm{K}_{\mathrm{d}}$ values for the complexes with $\mathrm{N}_{\mathrm{X}} \mathrm{CCaM}$ and $\mathrm{NC}_{\mathrm{X}} \mathrm{CaM}$ are respectively increased to $14.4 \pm 1.3$ and 36.7 $\pm 3.9 \mu \mathrm{M}$ (Fig. 3B, Table 1). Data for dissociation of the mutant $\mathrm{CaM}$ complexes as a function of the free $\mathrm{Ca}^{2+}$ concentration are presented in Fig. 4. Binding constants for the functional EF hand pair in each mutant complex can be estimated based on fits of these data to equation 2 (Table 2). The geometric means of the dissociation constants derived for the C-ter $\left(K_{1,2}\right)$ and $\mathrm{N}$-ter $\left(K_{3,4}\right) \mathrm{EF}$ hand pairs in bound 
$\mathrm{N}_{\mathrm{x}} \mathrm{CCaM}$ and $\mathrm{NC}_{\mathrm{x}} \mathrm{CaM}$ are $4.0 \pm 0.3$ and $33.8 \pm 4.0 \mu \mathrm{M}$; the corresponding values for the free mutant proteins are $1.6 \pm 0.2$ and $9.7 \pm 1.0$ (Table 2). Thus, the mean $\mathrm{Ca}^{2+}$-binding affinities of the functional EF hand pairs in both mutant CaMs are reduced 3 to 4-fold when they are associated with $\mathrm{BSCaM}_{\mathrm{IQ}}$.

\section{Measurements of $\mathrm{Ca}^{2+}$ binding to native and mutant $\mathrm{CaMs}$ in the presence and absence of BSCaM $_{I Q}$}

$\mathrm{Ca}^{2+}$-binding data measured in the presence and absence of $\mathrm{BSCaM}_{\mathrm{IQ}}$ are presented in Figs $5 \mathrm{~A}$ and 5B. Significant dissociation of $\mathrm{CaM}$ from the IQ domain is prevented during the course of these experiments by using at total concentration of $\mathrm{CaM}$ and $\mathrm{BSCaM}_{\mathrm{IQ}}$ that is $\sim 10$-fold or more above the $\mathrm{K}_{\mathrm{d}}$ value for the lowest affinity form of the complex. Otherwise, one observes the $\mathrm{Ca}^{2+}$ binding characteristics of a mixture of free and bound $\mathrm{CaM}$. Indeeed, this technique could not be applied to the complex between $\mathrm{NC}_{\mathrm{x}} \mathrm{CaM}-\mathrm{BSCaM} \mathrm{IQ}$ because a total protein concentration of $\sim 200 \mu \mathrm{M}$ is required to prevent dissociation of this complex at elevated free $\mathrm{Ca}^{2+}$ concentrations, which was found to be above the usable limit due to solubility problems.

The $\mathrm{Ca}^{2+}$-binding constants we have derived for native $\mathrm{CaM}$ are essentially identical to the literature values (27), and the correspondence between these values and those determined for the $\mathrm{N}_{\mathrm{x}} \mathrm{CCaM}$ and $\mathrm{NC}_{\mathrm{x}} \mathrm{CaM}$ mutants suggests that the presence of a non-functional $\mathrm{EF}$ hand pair in one $\mathrm{CaM}$ lobe does not significantly perturb $\mathrm{Ca}^{2+}$ binding to the other (Table 2 ). There is also reasonable agreement between the mean dissociation constants for the C-ter EF hand pair $\left(K_{1,2}\right)$ derived for the $\mathrm{N}_{\mathrm{x}} \mathrm{CCaM}-\mathrm{BSCaM}_{\mathrm{IQ}}$ complex based on data for $\mathrm{Ca}^{2+}$-dependent

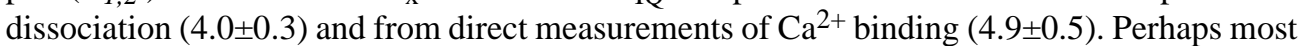
importantly, our results demonstrate that in the native $\mathrm{CaM}-\mathrm{BSCaM}_{\mathrm{IQ}}$ complex the affinity of the C-ter EF hand pair in CaM is decreased and the affinity of the N-ter EF hand pair is increased. These opposing effects result in similar mean dissociation constants of $5.1 \pm 0.7$ and $3.5 \pm 0.6 \mu \mathrm{M}$ for the two EF hand pairs. The first of these values is assumed to be $K_{1,2}$, the mean dissociation constant for the $\mathrm{C}$-ter $\mathrm{EF}$ hand pair, because it is closest to the value for the $\mathrm{N}_{\mathrm{X}} \mathrm{CCaM}-\mathrm{BSCaM} \mathrm{IQ}$ complex (Table 2).

\section{A general four-state mechanism for $\mathrm{Ca}^{2+}$-dependent switching in a CaM-target complex}

A general steady-state mechanism for $\mathrm{Ca}^{2+}$-dependent switching in a CaM-IQ domain complex is presented in Fig. 6. It includes the four major $\mathrm{Ca}^{2+}{ }_{-}$liganded forms of $\mathrm{CaM}$ : apoCaM (NC), $\mathrm{CaM}$ with two $\mathrm{Ca}^{2+}$ ions bound to the $\mathrm{C}$-ter $\left(\mathrm{NC}_{2}\right)$ or $\mathrm{N}$-ter $\left(\mathrm{N}_{2} \mathrm{C}\right) \mathrm{EF}$ hand pair, and $\mathrm{CaM}$ with $\mathrm{Ca}^{2+}$ bound to both $\mathrm{EF}$ hand pairs $\left(\mathrm{N}_{2} \mathrm{C}_{2}\right)$. In this model $\mathrm{Ca}^{2+}$ binding to the individual sites in an $\mathrm{EF}$ hand pair is treated as a single step governed by a $\mathrm{K}_{1} \mathrm{~K}_{2}$ or $\mathrm{K}_{3} \mathrm{~K}_{4}$ value.

\section{Thermodynamic relationships}

Thermodynamic linkage or energy coupling associated with formation of a CaM-target complex can be quantitively defined according to the relation:

$$
\Delta \Delta G_{C}=R T \ln \frac{K_{N_{2} C_{2}}}{K_{N C}}=R T \ln \frac{\left(K_{1} K_{2} K_{3} K_{4}\right)_{B}}{\left(K_{1} K_{2} K_{3} K_{4}\right)_{F}}
$$

where $\mathrm{K}_{1}$ and $\mathrm{K}_{2}$ are the $\mathrm{Ca}^{2+}$ binding constants for the C-ter $\mathrm{EF}$ hand pair and $\mathrm{K}_{3}$ and $\mathrm{K}_{4}$ are the constants for the N-ter pair. $K_{N C}$ and $K_{N_{2} C_{2}}$ are the dissociation constants for the apoCaM (NC) and $\left(\mathrm{Ca}^{2+}\right)_{4}-\mathrm{CaM}\left(\mathrm{N}_{2} \mathrm{C}_{2}\right)$ complexes with a target. The $F$ and $B$ subscripts identify the $\mathrm{Ca}^{2+}$ binding constants for free $\mathrm{CaM}$ and $\mathrm{CaM}$ bound to a target. These mathematical relationships formalize the basic thermodynamic requirement that a $\mathrm{Ca}^{2+}$-dependent change in the affinity of a CaM-target complex must be coupled to a corresponding change in the $\mathrm{Ca}^{2+}$-binding affinity of $\mathrm{CaM}$ when bound to the target. A negative $\Delta \Delta G_{C}$ value is produced when $\mathrm{Ca}^{2+}$ binding increases the affinity of $\mathrm{CaM}$ for a target. This is termed favorable or 
"positive" energy coupling because it is linked to an increase in $\mathrm{Ca}^{2+}$-binding affinity. A positive $\Delta \Delta G_{C}$ value is produced when $\mathrm{Ca}^{2+}$ binding decreases the affinity of CaM for a target. This type of energy coupling is termed unfavorable or "negative" because it is linked to a decrease in $\mathrm{Ca}^{2+}$-binding affinity. We can also define energy coupling in terms of the the individual $\mathrm{EF}$ hand pairs:

$$
\begin{aligned}
& \Delta \Delta G_{C}^{C}=R T \ln \alpha, \\
& \text { where } \alpha=\frac{K_{N C_{2}}}{K_{N C}}=\frac{\left(K_{1} K_{2}\right)_{B}}{\left(K_{1} K_{2}\right)_{F}} \\
& \Delta \Delta G_{C}^{N}=R T \ln \beta, \\
& \text { where } \beta=\frac{K_{N_{2} C_{2}}}{K_{N C_{2}}}=\frac{\left(K_{3} K_{4}\right)_{B}}{\left(K_{3} K_{4}\right)_{F}}
\end{aligned}
$$

The $C$ and $N$ superscripts designate the $\Delta \Delta G_{C}$ values for the C-ter and N-ter EF hand pairs. The proportionality constants $\alpha$ and $\beta$ are coupling coefficients; values less than one correspond with positive coupling and values greater than one correspond with negative coupling. As seen in Fig. 6, $\mathrm{Ca}^{2+}$ can in principal bind first to either the N-ter or C-ter EF hand pair, so two sets of coupling coefficients and $\Delta \Delta \mathrm{G}$ values must be considered. Unprimed symbols are used for the $\mathrm{C}$-ter $\rightarrow \mathrm{N}$-ter pathway, and primed symbols for the alternative $\mathrm{N}$-ter $\rightarrow \mathrm{C}$-ter pathway (see Fig. 6). Since the apoCaM and $\left(\mathrm{Ca}^{2+}\right)_{4}-\mathrm{CaM}$ complexes with $\mathrm{BSCaM}_{\mathrm{IQ}}$ have essentially identical affinities, the complete transition from one type of complex to the other cannot produce significant net energy coupling $\left(\Delta \Delta \mathrm{G}_{\mathrm{C}} \approx 0\right)$. In terms of the individual $\mathrm{EF}$ hand pairs this means that $\Delta \Delta G_{C}^{C}+\Delta \Delta G_{C}^{N} \approx \Delta \Delta G_{C}^{C^{\prime}}+\Delta \Delta_{C}^{N^{\prime}} \approx 0$ and $\alpha \beta \approx \alpha^{\prime} \beta^{\prime} \approx 1$. Thus, in spite of an overall lack of energy coupling, energetically opposing effects of $\mathrm{Ca}^{2+}$-binding to the two EF hand pairs are not precluded, and this is in fact what we have observed.

As seen in Table 3, $\alpha$ has a value of $\sim 8.5$, indicating negative coupling, while $\beta$ has a value of $\sim 0.14$, indicating positive coupling. The product of these values is $\sim 1.2$, satisfying the requirement that $\alpha \beta \approx 1$. Thus, along the $\mathrm{C}$-ter $\rightarrow \mathrm{N}$-ter pathway negatively coupled $\mathrm{Ca}^{2+}$ binding to the $\mathrm{C}$-ter $\mathrm{EF}$ hand pair, which necessarily reduces the affinity of the CaM$\mathrm{BSCaM}_{\mathrm{IQ}}$ complex, is followed by positively coupled binding to the N-ter EF hand, which in this case necessarily restores the affinity of the complex to its initial value. Based on the properties of the $\mathrm{NC}_{\mathrm{x}} \mathrm{CaM}-\mathrm{BSCaM} \mathrm{IQ}$ complex, we have estimated a value of $\sim 13.5$ for $\beta^{\prime}$, the coupling coefficient for the first step in the alternative $\mathrm{N}$-ter $\rightarrow$ C-ter pathway (Table 3 ). This pathway thus appears to be strongly disfavored for at least three reasons: (1) $\mathrm{The}^{\mathrm{Ca}^{2+} \text {-binding }}$ affinity of the N-ter EF hand pair in CaM is inherently $\sim 6$-fold lower than the affinity of the C-ter pair (Table 2), (2) The $\beta^{\prime}$ value is $\sim 2$-fold larger than the $\alpha$ value, which widens this inherent difference by $\sim 30 \%$. (3) The affinity of the $\mathrm{N}_{2} \mathrm{CCaM}$ complex with $\mathrm{BSCaM}_{\mathrm{IQ}}$ is 2fold lower than the affinity of the $\mathrm{NC}_{2} \mathrm{CaM}$ complex (Table 1). Thus, we can simplify our steady-state scheme by omitting the $\mathrm{N}$-ter $\rightarrow$ C-ter pathway (Fig. 7). This pathway is likely to be of greater importance under transient conditions because the N-ter EF hand pair binds $\mathrm{Ca}^{2+}$ more rapidly than the $\mathrm{C}$-ter pair (32).

\section{The transition between the apoCaM and $\left(\mathrm{Ca}^{2+}\right)_{4}-\mathrm{CaM}$ complexes with $\mathrm{BSCaM} \mathrm{IQ}_{\mathrm{Q}}$ and full- length neuromodulin}

The results we have presented thus far are consistent with a minimal biphasic mechanism (Fig. 7) in which the apparent affinity of the CaM-BSCaM IQ complex is decreased when $\mathrm{Ca}^{2+}$ is bound to the $\mathrm{C}$-ter $\mathrm{EF}$ hand pair in $\mathrm{CaM}$, and is restored to its initial value when $\mathrm{Ca}^{2+}$ is bound to the N-ter EF hand pair. This mechanism should produce a bell-shaped relationship between the apparent dissociation constant for the $\mathrm{CaM}-\mathrm{BSCaM}_{\mathrm{IQ}}$ complex and the free $\mathrm{Ca}^{2+}$ concentration. 
The fractional fluorescence response of $250 \mathrm{nM} \mathrm{BSCaM} \mathrm{IQ}_{\mathrm{IQ}}$ measured in the presence of 20 $\mu \mathrm{M} \mathrm{CaM}$ is plotted versus the free $\mathrm{Ca}^{2+}$ concentration in Fig. 8A. The $\mathrm{EC}_{50}\left(\mathrm{Ca}^{2+}\right)$ value for the transition between the apoCaM and $\left(\mathrm{Ca}^{2+}\right)_{4}-\mathrm{CaM}$ forms of the $\mathrm{CaM}-\mathrm{BSCaM}_{\mathrm{I}}$ complex is $2.5 \mu \mathrm{M}$, and there appears to be little dissociation of the complex at any free $\mathrm{Ca}^{2+}$ concentration. In contrast, the response of $5 \mu \mathrm{M}$ BSCaM $_{\mathrm{IQ}}$ measured in the presence of $1 \mu \mathrm{M}$ $\mathrm{CaM}$ is bell-shaped, consistent with significant dissociation of the complex at intermediate free $\mathrm{Ca}^{2+}$ concentrations. The amount of dissociation appears to be maximal at a free $\mathrm{Ca}^{2+}$ concentration of $\sim 6 \mu \mathrm{M}$, and the rising and falling phases of this relationship have $\mathrm{EC}_{50}\left(\mathrm{Ca}^{2+}\right)$ values of $\sim 2$ and $\sim 11 \mu \mathrm{M}$. The agreement between the observed $\mathrm{BSCaM}_{\mathrm{IQ}}$ fluorescence responses and the theoretical curves calculated based on our steady-state model is excellent under both sets of conditions (Fig. 8A, B).

To verify the applicability of our results to the complex between CaM and full-length neuromodulin, we employed fluorescently-labeled versions of CaM (ECFP-CaM) and fulllength neuromodulin $\left(\right.$ EYFP $_{\mathrm{C}}$-neuromodulin). As illustrated in Fig. $1 \mathrm{C}$, under $430 \mathrm{~nm}$ illumination formation of the complex between these proteins results in an increase in fluorescence emission at $525 \mathrm{~nm}$ due to FRET between the CFP and $\mathrm{EYFP}_{\mathrm{C}}$ moieties. The fractional fluorescence response of a mixture of $5 \mu \mathrm{M} \mathrm{EYFP}_{\mathrm{C}}$-neuromodulin and $1 \mu \mathrm{M} \mathrm{ECFP-}$ CaM is plotted as a function of the free $\mathrm{Ca}^{2+}$ concentration in Fig. 8B. This relationship has a more marked bell shape than the accompanying $\mathrm{BSCaM}_{\mathrm{IQ}}$ response determined under essentially identical experimental conditions. This is because the complexes between labeled neuromodulin and labeled apoCaM or $\left(\mathrm{Ca}^{2+}\right)_{4}$-CaM have the same fluorescence emission, while the complexes between the two forms of $\mathrm{CaM}$ and $\mathrm{BSCaM}_{\mathrm{IQ}}$ have different emissions (Table 1, Fig. 1B). These results clearly demonstrate that the apparent dissociation constants for the complexes between $\mathrm{CaM}$ and $\mathrm{BSCaM}_{\mathrm{IQ}}$ or full-length neuromodulin have similar biphasic dependencies on the free $\mathrm{Ca}^{2+}$ concentration.

\section{Discussion}

The relationship between the apparent dissociation constant for the complex between calmodulin $(\mathrm{CaM})$ and the neuromodulin IQ domain and the free $\mathrm{Ca}^{2+}$ concentration consists of two phases. In the first phase $\mathrm{Ca}^{2+}$ bound to the $\mathrm{C}$-ter $\mathrm{EF}$ hand pair in $\mathrm{CaM}$ increases the $\mathrm{K}_{\mathrm{d}}$ for the complex from the $\mathrm{Ca}^{2+}$-free value of $2.3 \pm 0.1 \mu \mathrm{M}$ to a value of $14.4 \pm 1.3 \mu \mathrm{M}$. In the second phase $\mathrm{Ca}^{2+}$ bound to the N-ter EF hand pair reduces the $\mathrm{K}_{\mathrm{d}}$ for the complex to a value of $2.5 \pm 0.1 \mu \mathrm{M}$, reversing the effect of the first phase. This behavior demonstrates that CaMIQ domain complexes can function as a biphasic $\mathrm{Ca}^{2+}$ switches through opposing effects of $\mathrm{Ca}^{2+}$ bound sequentially to the two EF hand pairs in CaM. In the case of neuromodulin these opposing effects serve to promote dissociation of $\mathrm{CaM}$ over a relatively narrow range of free $\mathrm{Ca}^{2+}$ concentrations.

Gaertner and coworkers (33) recently published a study of the $\mathrm{Ca}^{2+}$-dependencies of the CaMneurogranin complex. This protein has essentially the same IQ domain as neuromodulin, and it is thought to have a similar CaM-buffering function (34). These investigators report that $\mathrm{Ca}^{2+}$ is released from the CaM-neurogranin complex at an accelerated rate compared with the rate for free $\mathrm{CaM}$, consistent with negative coupling, although they were unable to verify this with steady-state $\mathrm{Ca}^{2+}$ binding measurements (33).

During a $\mathrm{Ca}^{2+}$ signal in an excitable cell such as a neuron CaM must be rapidly provided to targets like CaM kinase II that have high local concentrations $(35,36)$. It has been proposed that $\mathrm{CaM}$-binding proteins such as neuromodulin provide the required local stores of $\mathrm{CaM}$ (37-40). However, if neuromodulin were simply to release $\mathrm{CaM}$ above a threshold free $\mathrm{Ca}^{2+}$ concentration, any not taken up by targets would be free to diffuse away until the free $\mathrm{Ca}^{2+}$ concentration fell below this threshold. Our results suggest that release of CaM from 
neuromodulin is promoted only within a relatively narrow 5 to 6 -fold range in the free $\mathrm{Ca}^{2+}$ concentration. Our current hypothesis is that during a $\mathrm{Ca}^{2+}$ transient in a neuron the local free $\mathrm{Ca}^{2+}$ concentration passes rapidly through this range, producing a transient burst of free $\mathrm{CaM}$ that rebinds neuromodulin if not taken up by targets. Maintenance of a defined distribution of $\mathrm{CaM}$ through this and similar mechanisms may be of particular importance in neurons and other cells whose specific responses to different types of $\mathrm{Ca}^{2+}$ signals suggest a high degree of spatial discrimination (41-43).

The concentrations of the major species produced in a solution of CaM and neuromodulin as a function of the free $\mathrm{Ca}^{2+}$ concentration can be calculated based the minimal mechanism presented in Fig. 7 and the parameters listed in Tables 1 and 2. Given physiologically reasonable total neuromodulin and $\mathrm{CaM}$ concentrations of $10 \mu \mathrm{M}$, these calculations indicate that essentially all of the $\mathrm{CaM}$ remains $\mathrm{Ca}^{2+}$-free at $\mathrm{Ca}^{2+}$ concentrations below $0.1 \mu \mathrm{M}$, with $\sim 60 \%$ of the protein bound to the IQ domain. As the free $\mathrm{Ca}^{2+}$ concentration is increased the total concentration of free CaM rises by $\sim 40 \%$ with an $\mathrm{EC}_{50}\left(\mathrm{Ca}^{2+}\right)$ of $\sim 2 \mu \mathrm{M}$, peaks at a free $\mathrm{Ca}^{2+}$ concentration of $\sim 5 \mu \mathrm{M}$, and declines back to the starting value with an $\mathrm{EC}_{50}\left(\mathrm{Ca}^{2+}\right)$ of $\sim 10 \mu \mathrm{M}$. To place the range of free $\mathrm{Ca}^{2+}$ concentrations over which this occurs in a physiological context, it appears that local free $\mathrm{Ca}^{2+}$ concentrations as high as 50-100 $\mu \mathrm{M}$ are produced in a variety of cell types, including neurons (44-49). There is of course also an inverse bell-shaped relationship between the concentration of the CaM-IQ domain protein complex and the free $\mathrm{Ca}^{2+}$ concentration. This highlights the possibility that the switching mechanism we have identified produces biphasic responses in the activities of some IQ domain proteins.

\section{References}

1. Yagi K, Yazawa M, Kakiuchi S, Ohshima M, Uenishi K. Identification of an activator protein for myosin light chain kinase as the $\mathrm{Ca}^{2+}$-dependent modulator protein. J Biol Chem 1978;253:13381340. [PubMed: 627540]

2. Bredt DS, Snyder SH. Isolation of nitric oxide synthetase, a calmodulin-requiring enzyme. Proc Nat Acad Sci USA 1990;87:682-685. [PubMed: 1689048]

3. Venema RC, Sayegh HS, Arnal JF, Harrison DG. Role of the enzyme calmodulin-binding domain in membrane association and phospholipid inhibition of endothelial nitric oxide synthase. J Biol Chem 1995;270:14705-14711. [PubMed: 7540177]

4. Dabrowska R, Sherry JM, Aromatorio DK, Hartshorne DJ. Modulator protein as a component of the myosin light chain kinase from chicken gizzard. Biochemistry 1978;17:253-258. [PubMed: 202300]

5. Jurado LA, Chockalingam PS, Jarrett HW. Apocalmodulin. Physiol Rev 1999;79:661-682. [PubMed: 10390515]

6. Bahler M, Rhoads A. Calmodulin signaling via the IQ motif. FEBS Lett 2002;513:107-113. [PubMed: 11911888]

7. Estep RP, Alexander KA, Storm DR. Regulation of free calmodulin levels in neurons by neuromodulin: relationship to neuronal growth and regeneration. Curr Top Cell Regul 1990;31:161-180. [PubMed: 2147138]

8. Tran QK, Black DJ, Persechini A. Intracellular coupling via limiting calmodulin. J Biol Chem 2003;278:24247-24250. [PubMed: 12738782]

9. Rakhilin SV, Olson PA, Nishi A, Starkova NN, Fienberg AA, Nairn AC, Surmeier DJ, Greengard P. A network of control mediated by regulator of calcium/calmodulin-dependent signaling. Science 2004;306:698-701. [PubMed: 15499021]

10. Isotani E, Zhi G, Lau KS, Huang J, Mizuno Y, Persechini A, Geguchadze R, Kamm KE, Stull JT. Real-time evaluation of myosin light chain kinase activation in smooth muscle tissues from a transgenic calmodulin-biosensor mouse. Proc Natl Acad Sci USA 2004;101:6279-6284. [PubMed: 15071183]

11. Tran QK, Black DJ, Persechini A. Dominant affectors in the calmodulin network shape the time courses of target responses in the cell. Cell Calcium 2005;37:541-553. [PubMed: 15862345] 
12. Gnegy ME. Calmodulin: effects of cell stimuli and drugs on cellular activation. Prog Drug Res 1995;45:33-65. [PubMed: 8545541]

13. Gerendasy DD, Herron SR, Watson JB, Sutcliffe JG. Mutational and biophysical studies suggest RC3/neurogranin regulates calmodulin availability. J Biol Chem 1994;269:22420-22426. [PubMed: 8071370]

14. Persechini A, Cronk B. The relationship between the free concentrations of $\mathrm{Ca}^{2+}$ and $\mathrm{Ca}^{2+}-$ calmodulin in intact cells. J Biol Chem 1999;274:6827-6830. [PubMed: 10066733]

15. Persechini A, Stemmer PM. Calmodulin is a limiting factor in the cell. Trends Cardiovasc Med 2002;12:32-37. [PubMed: 11796242]

16. Griesbeck O, Baird GS, Campbell RE, Zacharias DA, Tsien RY. Reducing the environmental sensitivity of yellow fluorescent protein - Mechanism and applications. J Biol Chem 2001;276:29188-29194. [PubMed: 11387331]

17. Chapman ER, Au D, Alexander KA, Nicolson TA, Storm DR. Characterization of the calmodulin binding domain of neuromodulin. Functional significance of serine 41 and phenylalanine 42 . J Biol Chem 1991;266:207-213. [PubMed: 1824693]

18. Persechini A. Monitoring the intracellular free $\mathrm{Ca}(2+)$-calmodulin concentration with geneticallyencoded fluorescent indicator proteins. Methods Mol Biol 2002;173:365-382. [PubMed: 11859776]

19. Fruen BR, Black DJ, Bloomquist RA, Bardy JM, Johnson JD, Louis CF, Balog EM. Regulation of the RYR1 and RYR2 Ca2+ release channel isoforms by Ca2+-insensitive mutants of calmodulin. Biochemistry 2003;42:2740-2747. [PubMed: 12614169]

20. Tang W, Halling DB, Black DJ, Pate P, Zhang JZ, Pedersen S, Altschuld RA, Hamilton SL. Apocalmodulin and $\mathrm{Ca} 2+$ calmodulin-binding sites on the $\mathrm{Ca}(\mathrm{V}) 1.2$ channel. Biophys $\mathrm{J}$ 2003;85:1538-1547. [PubMed: 12944271]

21. Black DJ, Tran QK, Persechini A. Monitoring the total available calmodulin concentration in intact cells over the physiological range in free Ca2+Cell Calcium 2004;35:415-425. [PubMed: 15003851]

22. Haiech J, Klee CB, Demaille JG. Effects of cations on affinity of calmodulin for calcium: ordered binding of calcium ions allows the specific activation of calmodulin-stimulated enzymes. Biochemistry 1981;20:3890-3897. [PubMed: 7272283]

23. Kilhoffer M-C, Kubina M, Travers F, Haiech J. Use of engineered proteins with internal tryptophan reporter groups and perturbation techniques to probe th emechanism of ligand-protein ineteractions: Investigation of the mechanism of calcium binding to calmodulin. Biochemistry 1992;31:8098-8106. [PubMed: 1510991]

24. Evenas J, Malmendal A, Thulin E, Carlstrom G, Forsen S. Ca2+ Binding and Conformational Changes in a Calmodulin Domain. Biochemistry 1998;37:13744-13754. [PubMed: 9753463]

25. Malmendal A, Evenas J, Forsen S, Akke M. Structural dynamics in the C-terminal domain of calmodulin at low calcium levels. J Mol Biol 1999;293:883-899. [PubMed: 10543974]

26. Linse S, Johansson C, Brodin P, Grundström T, Drakenberg T, Forsén S. Electrostatic contributions to the binding of $\mathrm{Ca}^{2+}$ in calbindin $\mathrm{D}_{9 \mathrm{k}}$. Biochemistry 1991;30:154-162. [PubMed: 1988017]

27. Linse S, Helmersson A, Forsen S. Calcium binding to calmodulin and its globular domains. J Biol Chem 1991;266:8050-8054. [PubMed: 1902469]

28. Andre I, Linse S. Measurement of Ca2+-binding constants of proteins and presentation of the CaLigator software. Anal Biochem 2002;305:195-205. [PubMed: 12054448]

29. Alexander K, Cimler B, Meier K, Storm D. Regulation of calmodulin binding to P-57. A neurospecific calmodulin binding protein. J Biol Chem 1987;262:6108-6113. [PubMed: 2952648]

30. Alexander K, Wakim B, Doyle G, Walsh K, Storm D. Identification and characterization of the calmodulin-binding domain of neuromodulin, a neurospecific calmodulin-binding protein. J Biol Chem 1988;263:7544-7549. [PubMed: 2967288]

31. Carlstrom G, Chazin WJ. Two-dimensional $1 \mathrm{H}$ nuclear magnetic resonance studies of the halfsaturated $(\mathrm{Ca} 2+) 1$ state of calbindin D9k. Further implications for the molecular basis of cooperative Ca2+ binding. J Mol Biol 1993;231:415-430. [PubMed: 8389885]

32. Forsén, S.; Vogel, HJ.; Drakenberg, T. Biophysical studies of calmodulin. In: Cheung, WY., editor. Calcium and Cell Function. Academic Press; New York: 1986. p. 113-157. 
33. Gaertner TR, Putkey JA, Waxham MN. RC3/neurogranin and Ca2+/calmodulin-dependent protein kinase II produce opposing effects on the affinity of calmodulin for calcium. J Biol Chem 2004;279:39374-39382. [PubMed: 15262982]

34. Baudier J, Deloulme JC, Van Dorsselaer A, Black D, Matthes HW. Purification and characterization of a brain-specific protein kinase $C$ substrate, neurogranin (p17). Identification of a consensus amino acid sequence between neurogranin and neuromodulin (GAP43) that corresponds to the protein kinase C phosphorylation site and the calmodulin-binding domain. J Biol Chem 1991;266:229-237. [PubMed: 1824695]

35. Strack S, Choi S, Lovinger DM, Colbran RJ. Translocation of Autophosphorylated Calcium/ Calmodulin-Dependent Protein Kinase II to the Postsynaptic Density. J Biol Chem 1997;272:1346713470. [PubMed: 9153188]

36. Colbran RJ, Soderling TR. Calcium/calmodulin-dependent protein kinase II. Curr Topics Cell Reg 1990;31:181-221.

37. Prichard L, Deloulme JC, Storm DR. Interactions between Neurogranin and Calmodulin in Vivo. J Biol Chem 1999;274:7689-7694. [PubMed: 10075657]

38. Gamby C, Waage MC, Allen RG, Baizer L. Growth-associated protein-43 (GAP-43) facilitates peptide hormone secretion in mouse anterior pituitary AtT-20 cells. J Biol Chem 1996;271:1002310028. [PubMed: 8626556]

39. Gamby C, Waage MC, Allen RG, Baizer L. Analysis of the Role of Calmodulin Binding and Sequestration In Neuromodulin (GAP-43) Function. J Biol Chem 1996;271:26698-26705. [PubMed: 8900147]

40. Gerendasy DD, Sutcliffe JG. RC3/NEUROGRANIN, A POSTSYNAPTIC CALPACITIN FOR SETTING THE RESPONSE THRESHOLD TO CALCIUM INFLUXES [Review]. Mol Neurobiol 1997;15:131-163. [PubMed: 9396008]

41. Hernandez-Cruz A, Sala F, Adams PR. Subcellular calcium transients visualized by confocal microscopy in a voltage-clamped vertebrate neuron. Science 1990;247:858-862. [PubMed: 2154851]

42. Deisseroth K, Heist EK, Tsien RW. Translocation of Calmodulin to the Nucleus Supports CREB Phosphorylation In Hippocampal Neurons. Nature 1998;392:198-202. [PubMed: 9515967]

43. Bito H, Deisseroth K, Tsien RW. CREB phosphorylation and dephosphorylation: $\mathrm{a} \mathrm{Ca}^{2+}$ - and stimulus duration-dependent switch for hippocampal gene expression. Cell 1996;87:1203-1214. [PubMed: 8980227]

44. Etter EF, Minta A, Poenie M, Fay FS. Near-membrane $\left[\mathrm{Ca}^{2+}\right]$ transients resolved using the $\mathrm{Ca}^{2+}$ indicator FFP18. Proc Natl Acad Sci USA 1996;93:5368-5373. [PubMed: 8643581]

45. Marsault R, Murgia M, Pozzan T, Rizzuto R. Domains of high $\mathrm{Ca}^{2+}$ beneath the plasma membrane of living A7r5 cells. EMBO J 1997;16:1575-1581. [PubMed: 9130702]

46. Davies EV, Hallett MB. High micromolar $\mathrm{Ca}^{2+}$ beneath the plasma membrane in stimulated neutrophils. Biochem Biophys Res Commun 1998;248:679-683. [PubMed: 9703986]

47. Klingauf J, Neher E. Modeling Buffered $\mathrm{Ca}^{2+}$ Diffusion Near the Membrane - Implications For Secretion In Neuroendocrine Cells. Biophys J 1997;72:674-690. [PubMed: 9017195]

48. Simon SM, Llinas RR. Compartmentalization of the submembrane calcium activity during calcium influx and its significance in transmitter release. Biophys J 1985;48:485-498. [PubMed: 2412607]

49. Llinas R, Moreno H. Local $\mathrm{Ca}^{2+}$ signaling in neurons. Cell Calcium 1998;24:359-366. [PubMed: 10091005] 

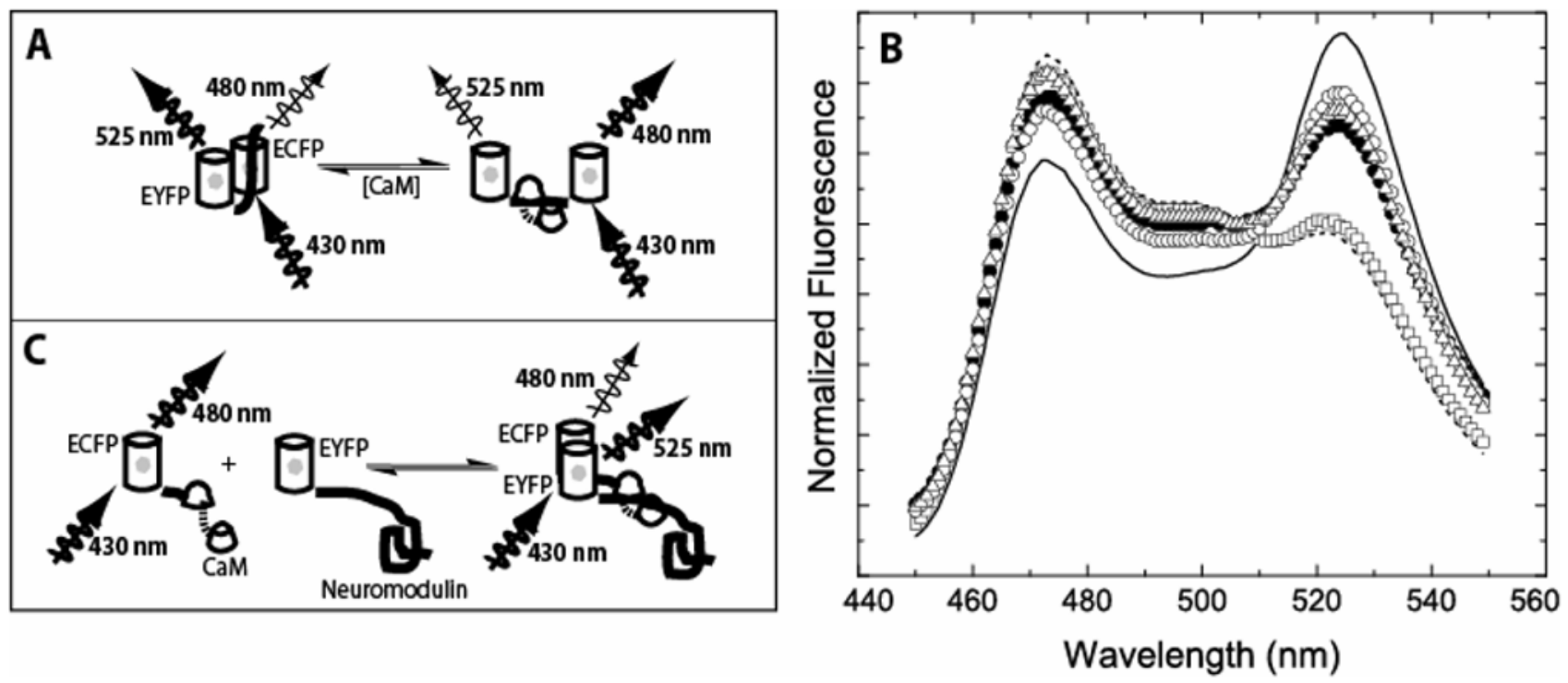

Fig. 1. Fluorescent reporter systems used to monitor interactions between $\mathrm{CaM}$ and the neuromodulin IQ domain. (A)

BSCaM $_{\mathrm{IQ}}$ consists of ECFP and EYFP variants of GFP joined by an IQ domain. When CaM is bound to this domain changes in the orientation and/or distance between the two fluorescent proteins decrease fluorescence resonance energy transfer (FRET) between the ECFP and EYFP components. Thus, under $430 \mathrm{~nm}$ excitation ECFP donor fluorescence, measured at $480 \mathrm{~nm}$, is increased and EYFP acceptor fluorescence, measured at $525 \mathrm{~nm}$, is decreased. (B) Complete fluorescence emission spectra for $\mathrm{BSCaM}_{\mathrm{IQ}}$ under $430 \mathrm{~nm}$ excitation. The solid line is the emission spectrum determined in the absence of $\mathrm{CaM}$, the dashed line is the spectrum determined in the presence of a saturating apoCaM concentration. The remaining spectra were determined in the presence of saturating concentrations of $\mathrm{Ca}^{2+}$-free $\mathrm{NC}_{\mathrm{X}} \mathrm{CaM}$ or $\mathrm{N}_{\mathrm{x}} \mathrm{CCaM}$ $(\square), \mathrm{Ca}^{2+}$-saturated native $\mathrm{CaM}(\bullet), \mathrm{N}_{\mathrm{x}} \mathrm{C}_{2} \mathrm{CaM}(\mathrm{O})$ and $\mathrm{N}_{2} \mathrm{C}_{\mathrm{x}} \mathrm{CaM}(\Delta)$. (C) A bipartite reporter system consisting of ECFP-CaM and EYFP-neuromodulin fusion proteins. As illustrated in the figure, formation of the complex between $\mathrm{CaM}$ and neuromodulin allows FRET between the ECFP and EYFP labels to occur under $430 \mathrm{~nm}$ excitation. 


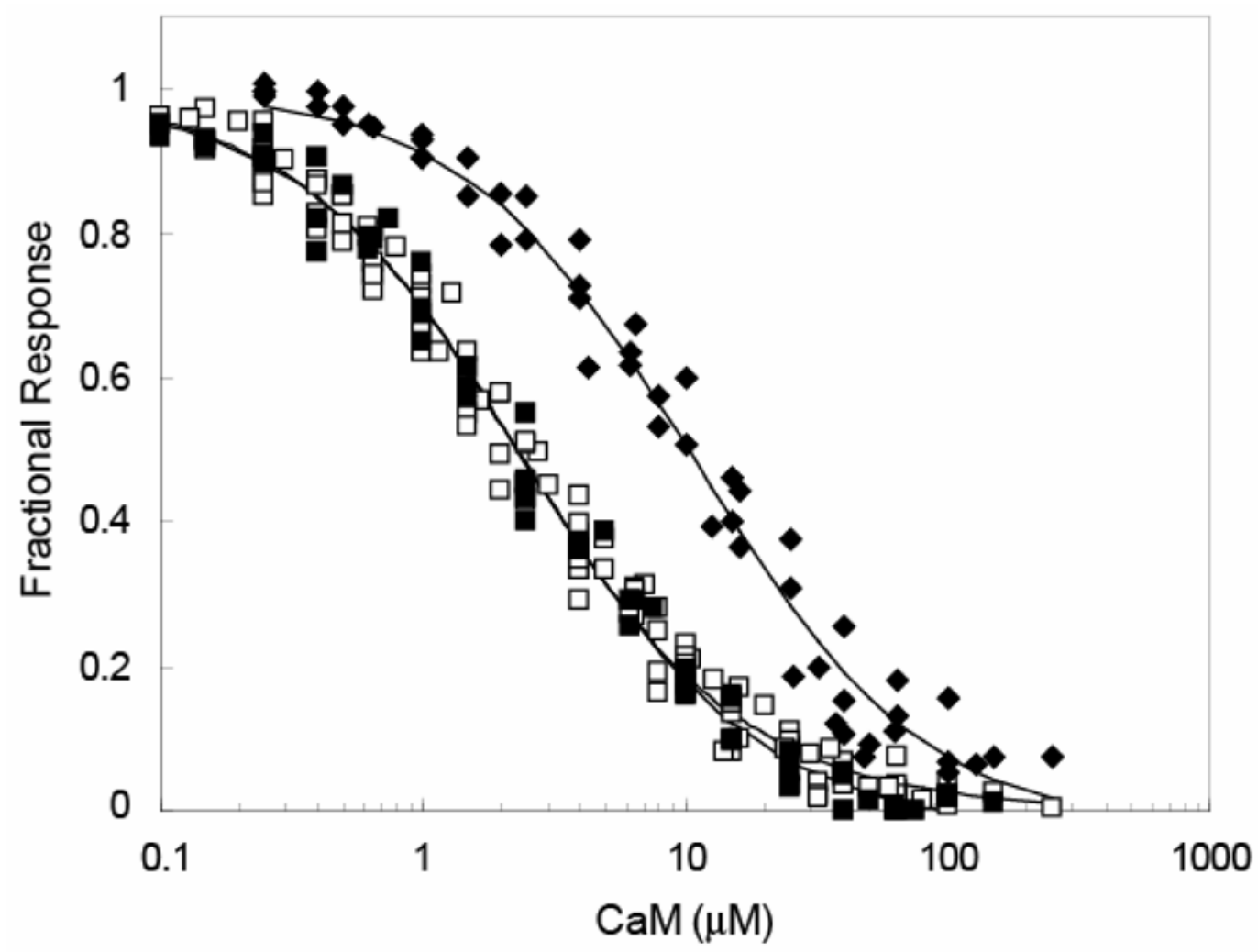

Fig. 2. Binding of CaM to BSCaM $\mathrm{BQ}_{\mathrm{Q}}$ in the presence of $10(\checkmark)$ and $250(\square) \mu \mathrm{M}$ free $\mathrm{Ca}^{2+}$, or $3 \mathrm{mM}$ BAPTA (ロ)

The fractional change in $525 \mathrm{~nm}$ fluorescence produced by the decrease in FRET associated with formation of the complex is defined as $\left(\mathrm{F}_{\max }-\mathrm{F}\right) /\left(\mathrm{F}_{\max }-\mathrm{F}_{\min }\right)$, where $\mathrm{F}$ corresponds with the emission measured after each addition, and $\mathrm{F}_{\max }$ and $\mathrm{F}_{\min }$ correspond with the emissions of CaM-free and CaM-saturated $\mathrm{BSCaM}_{\mathrm{IQ}}$. A $50 \mu \mathrm{M}$ BSCaM $\mathrm{BQ}_{\mathrm{IQ}}$ concentration was used for these experiments. The apparent $\mathrm{K}_{\mathrm{d}}$ values determined from fits of these data to a simple onesite hyperbolic binding equation (not shown) are listed in Table 1. 


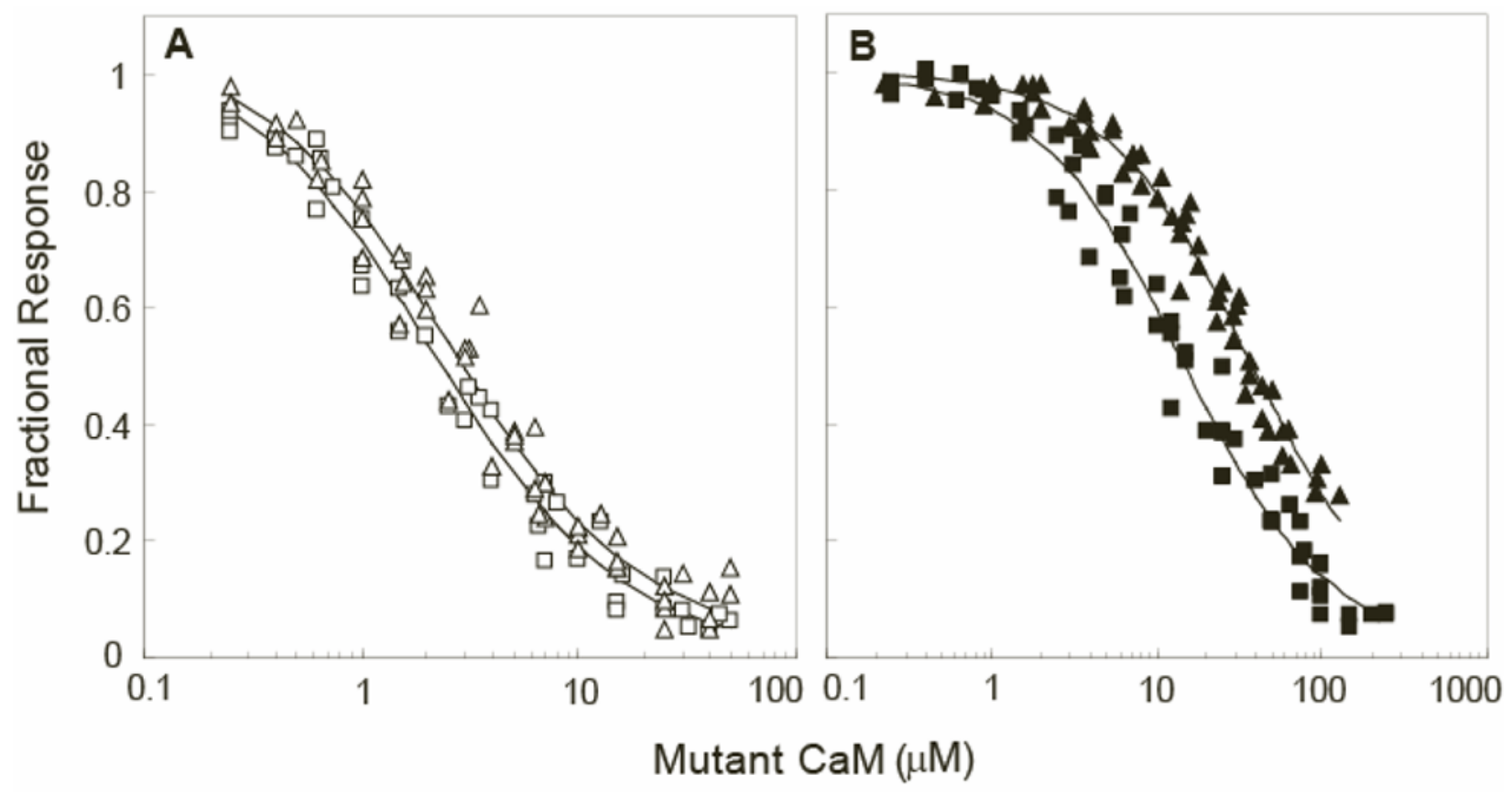

Fig. 3. Binding of $\mathrm{N}_{\mathrm{x}} \mathrm{CCaM}$ or $\mathrm{NC}_{\mathrm{x}} \mathrm{CaM}$ to $\mathrm{BSCaM} \mathrm{IQ}$

(A) Fractional changes in $525 \mathrm{~nm}$ fluorescence emission, defined as described in the legend to Fig. 2, associated with binding of $\mathrm{N}_{\mathrm{x}} \mathrm{CCaM}(\square)$ or $\mathrm{NC}_{\mathrm{X}} \mathrm{CaM}(\triangle)$ to $50 \mathrm{nM}$ BSCaM $\mathrm{IQ}_{\mathrm{Q}}$ under nominally $\mathrm{Ca}^{2+}$ free conditions (3 mM BAPTA). (B) Fractional changes in $525 \mathrm{~nm}$ fluorescence emission associated with binding of $\mathrm{N}_{\mathrm{x}} \mathrm{CCaM}(\boldsymbol{\bullet})$ and $\mathrm{NC}_{\mathrm{x}} \mathrm{CaM}(\boldsymbol{\Delta})$ to $150 \mathrm{nM}$ $\mathrm{BSCaM}_{\mathrm{IQ}}$ at a free $\mathrm{Ca}^{2+}$ concentration of $\sim 250 \mu \mathrm{M}$. Apparent $\mathrm{K}_{\mathrm{d}}$ values derived from the data presented in panels A and B are listed in Table 1. 


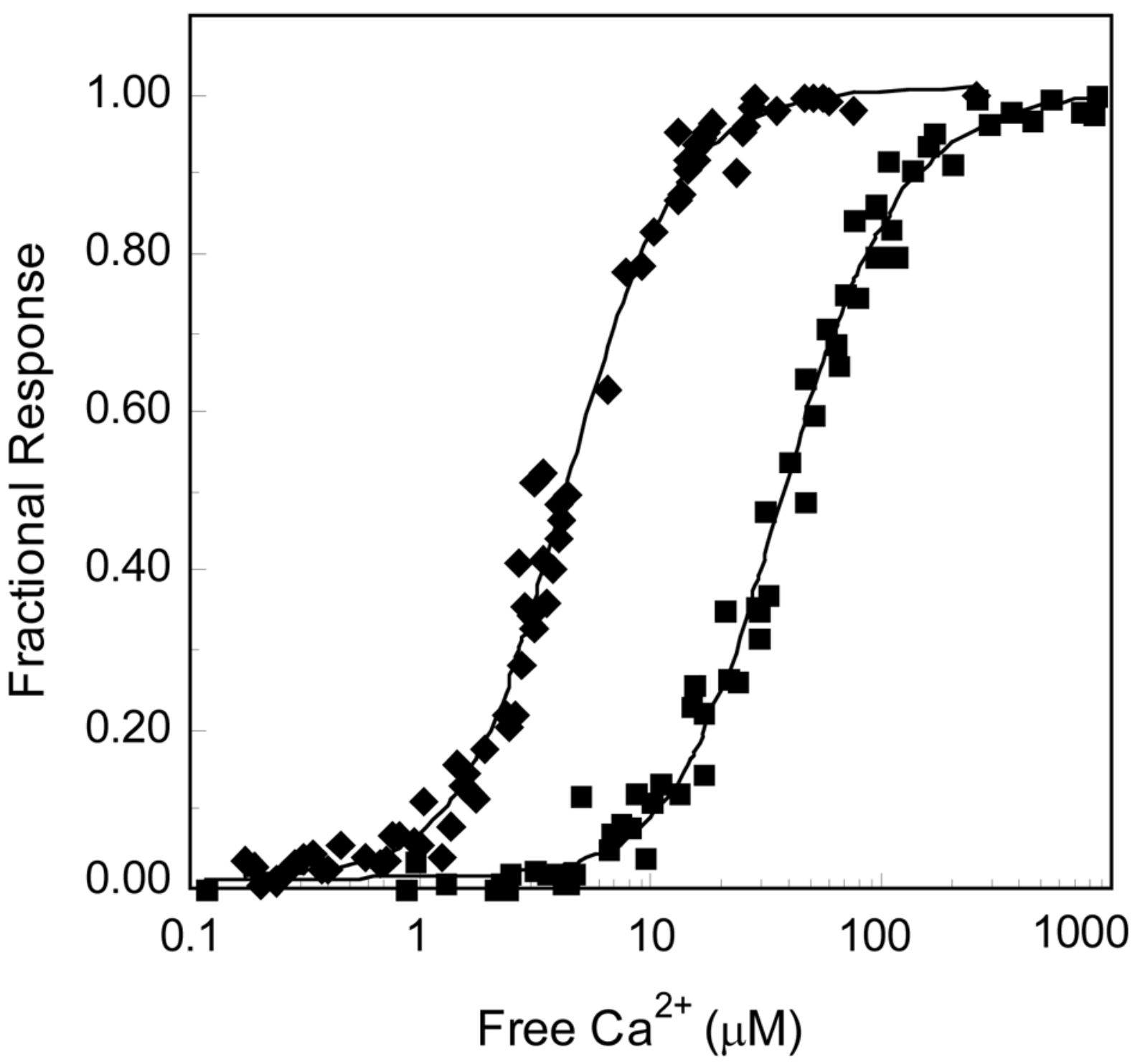

Fig. 4. $\mathrm{Ca}^{2+}$-dependent dissociation of the $\mathrm{N}_{\mathrm{x}} \mathrm{CCaM}$ or $\mathrm{NC}_{\mathrm{x}} \mathrm{CaM}$ complexes with $\mathrm{BSCaM}_{\mathrm{IQ}}$ Fractional changes in $525 \mathrm{~nm}$ fluorescence emission associated with formation of the complexes between $12.5 \mu \mathrm{M} \mathrm{BSCaM}_{\mathrm{IQ}}$ and $1 \mu \mathrm{M} \mathrm{N} \mathrm{N}_{\mathrm{x}} \mathrm{CCaM}(\boldsymbol{)})$ or $\mathrm{NC}_{\mathrm{x}} \mathrm{CaM}(\boldsymbol{\bullet})$. All free $\mathrm{Ca}^{2+}$ concentrations were verified using indo-5F or mag-indo-1. Fractional changes in fluorescence are defined using an $\mathrm{F}_{\max }$ value measured at the end of the experiment, which accounts for residual $\mathrm{CaM}$ binding in the presence of $\mathrm{Ca}^{2+}$. Otherwise fractional changes are defined as described in the legend to Fig. 2. Apparent $\mathrm{Ca}^{2+}$-binding constants derived from fits of these data to equation 2 are listed in Table 2. 


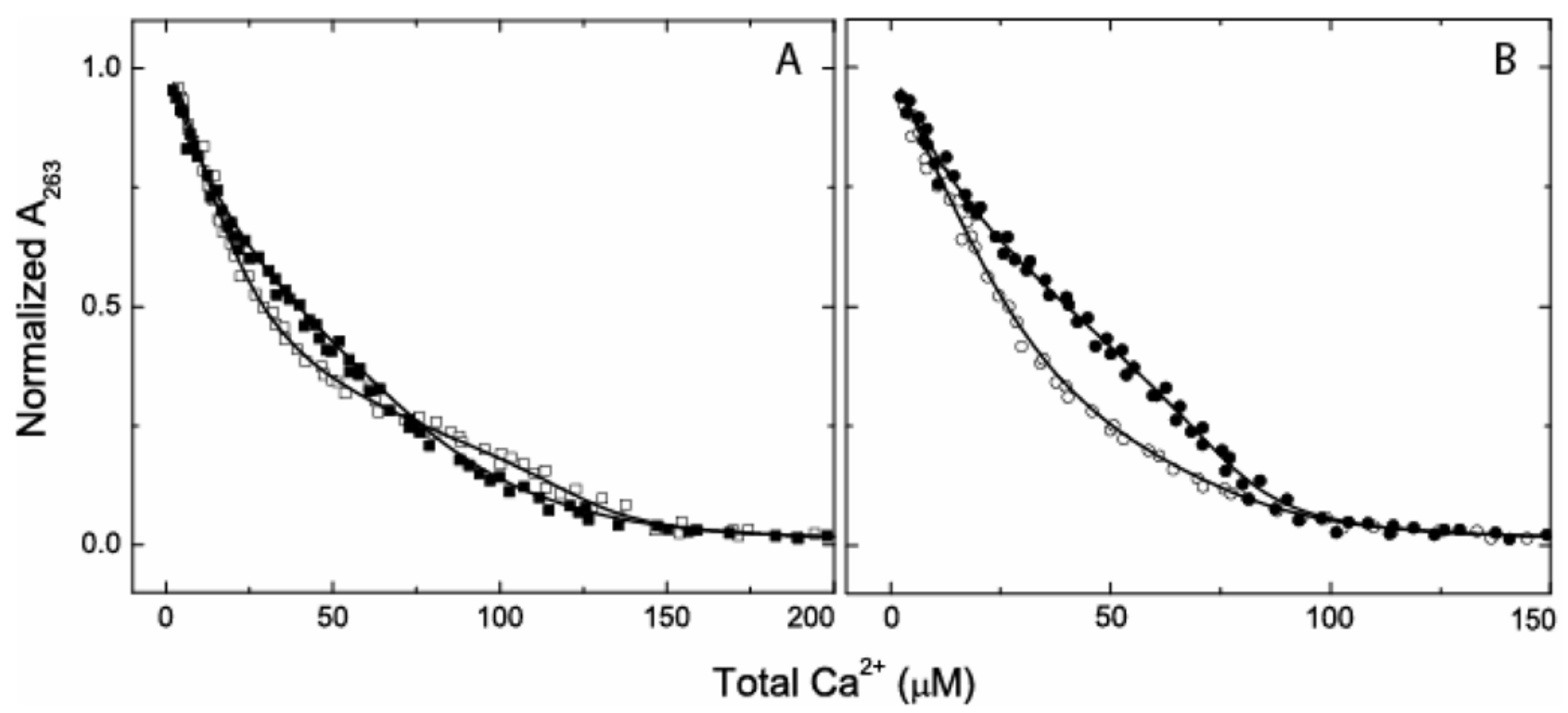

Fig. 5. Direct measurements of $\mathrm{Ca}^{2+}$ binding to native and mutant $\mathrm{CaMs}$ in the presence and absence of $\mathrm{BSCaM}_{\mathrm{IQ}}$

(A) $263 \mathrm{~nm}$ absorbance data for $40 \mu \mathrm{M}$ dibromo-BAPTA measured in the presence of $20 \mu \mathrm{M}$ native $\mathrm{CaM}(\mathbf{})$ or $20 \mu \mathrm{M}$ native $\mathrm{CaM}$ and $100 \mu \mathrm{M}$ BSCaM $_{\mathrm{IQ}}$ ( $\square$ ). (B) Absorbance data for 40 $\mu \mathrm{M}$ dibromo-BAPTA measured the presence of $20 \mu \mathrm{M} \mathrm{N} \mathrm{N}_{\mathrm{x}} \mathrm{CCaM}(\bullet)$ or $20 \mu \mathrm{M} \mathrm{N}_{\mathrm{x}} \mathrm{CCaM}$ and $100 \mu \mathrm{M} \mathrm{BSCaM}_{\mathrm{IQ}}(\mathrm{\circ})$. For presentation purposes these data have been normalized to the absorbance of $\mathrm{Ca}^{2+}$-free dibromo-BAPTA determimed at the completion of each titration experiment. Pooled data from 3 separate $\mathrm{Ca}^{2+}$ binding experiments are presented for each set of conditions examined. The dissociation constants derived from fits of these and similar data to equation 3 or 4 are listed in Table 2 (28). 


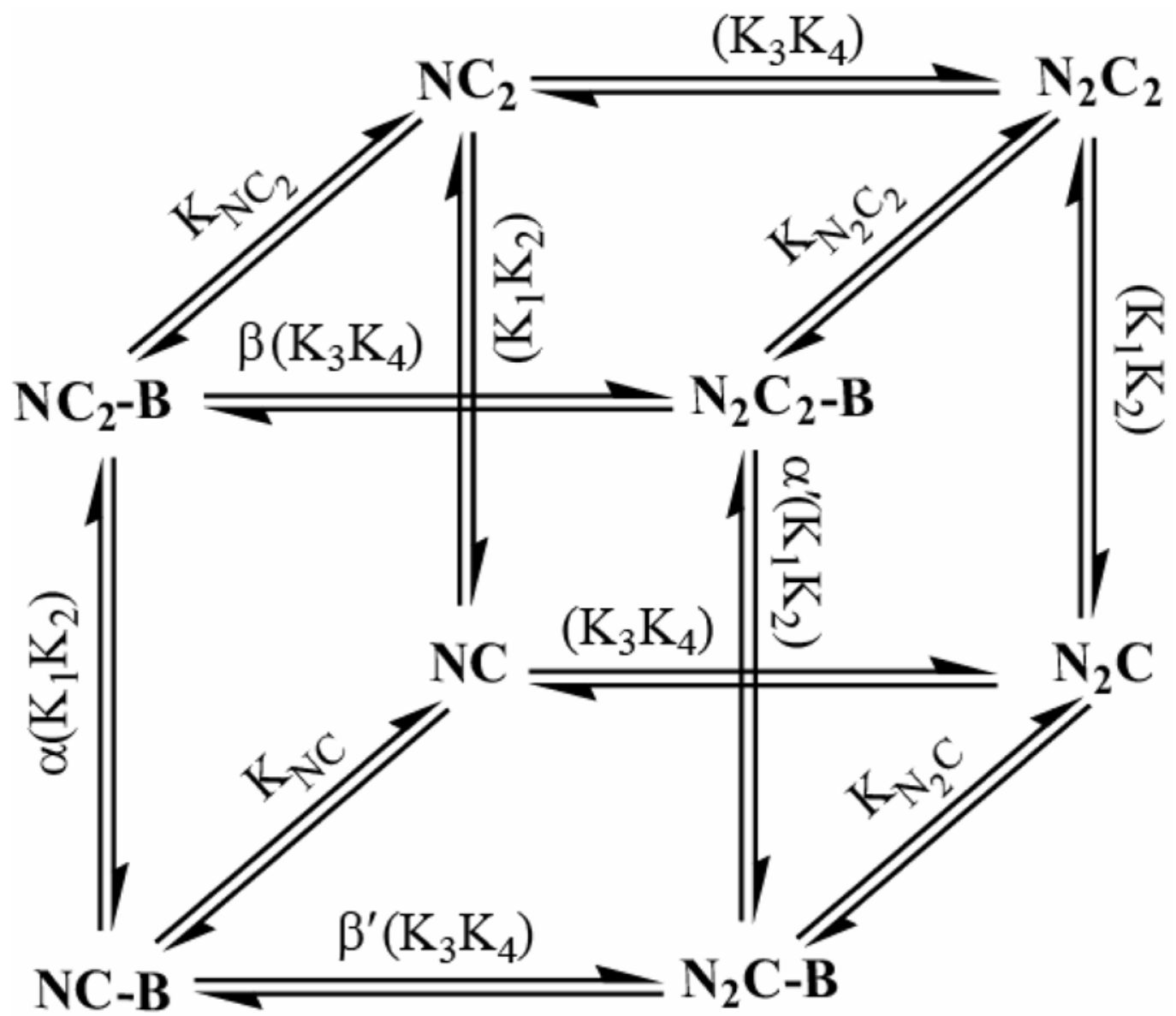

Fig. 6. A general four-state scheme for $\mathrm{Ca}^{2+}$-dependent switching in a CaM-IQ domain complex $\mathrm{B}$ indicates the bound IQ domain protein; $\mathrm{N}$ and $\mathrm{C}$ indicate the $\mathrm{N}$-ter and $\mathrm{C}$-ter $\mathrm{EF}$ hand pairs in $\mathrm{CaM}$, with subscripts denoting their $\mathrm{Ca}^{2+}$-liganded states; the absence of a subscript indicates a $\mathrm{Ca}^{2+}$-free EF hand pair. 


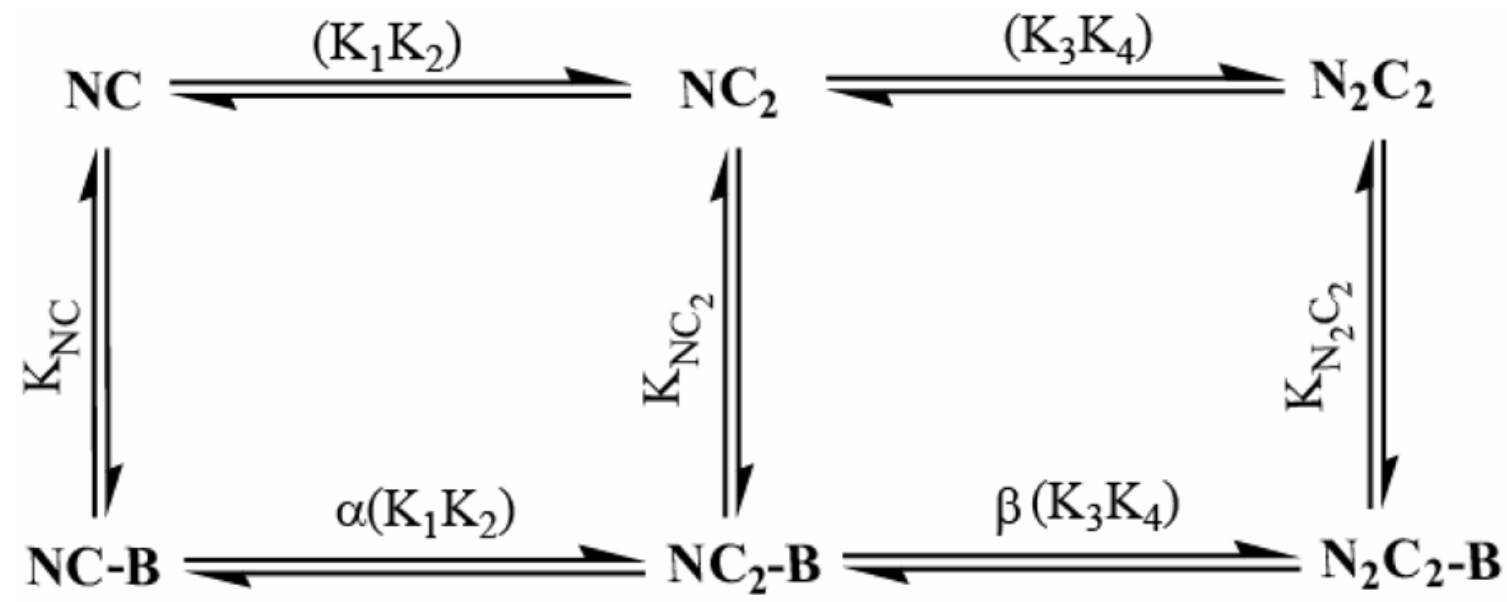

Fig. 7. Minimal scheme for $\mathrm{Ca}^{2+}$-dependent switching in the neuromodulin CaM-IQ domain complex

$\mathrm{Ca}^{2+}$ binding via the $\mathrm{N}$-ter $\rightarrow \mathrm{C}$-ter pathway depicted in the general scheme appears to be strongly disfavored, so it can be omitted from the minimal scheme describing the $\mathrm{Ca}^{2+}$ dependence of the CaM-neuromodulin complex under steady-state conditions. 


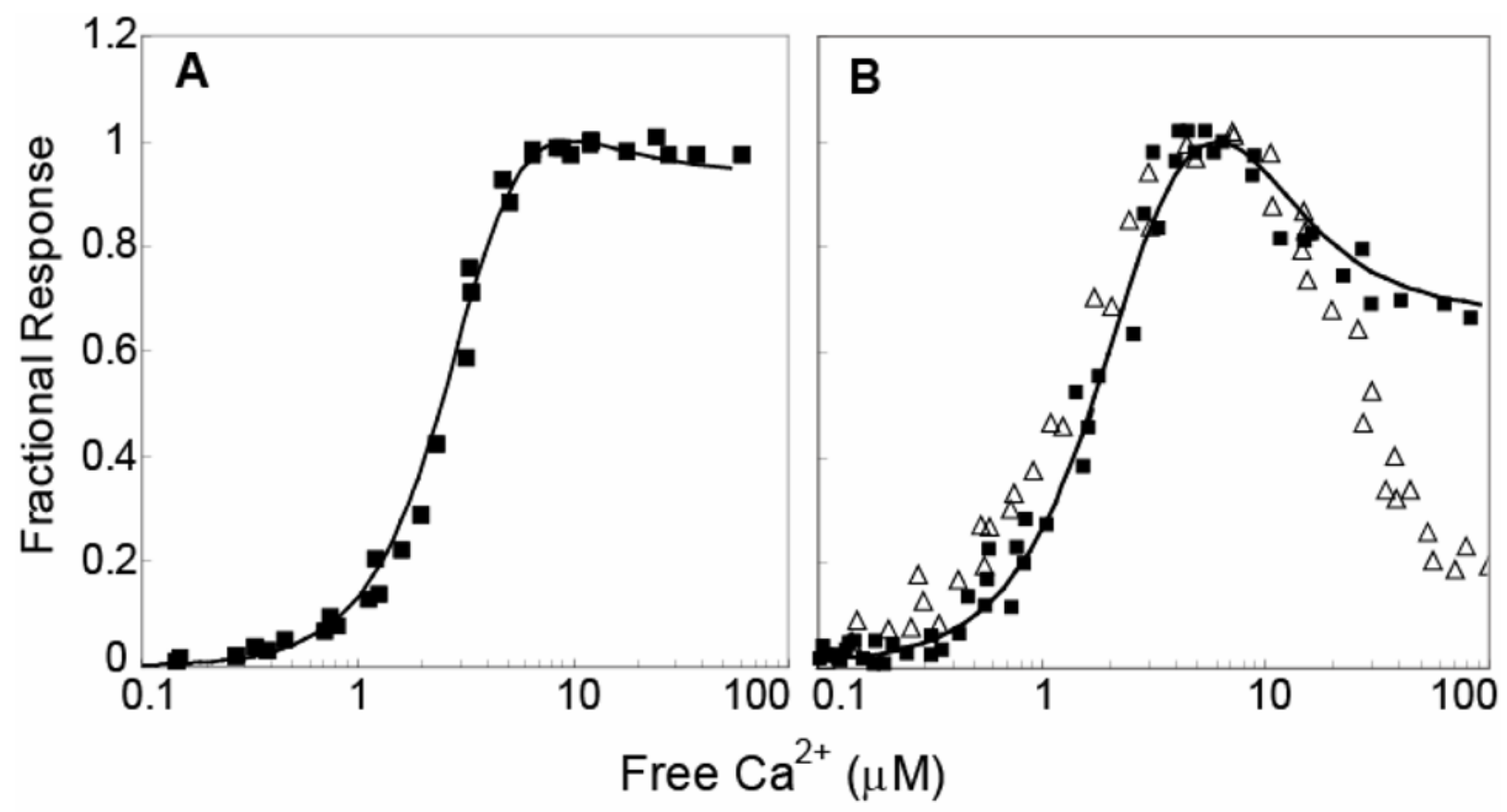

Fig. 8. The relationship between the free $\mathrm{Ca}^{2+}$-concentration and the dissociation constant for the complex between CaM and the neuromodulin IQ domain is bell shaped

All free $\mathrm{Ca}^{2+}$ concentrations were verified using indo-5F or mag-indo-1. (A) The fractional fluorescence response of $250 \mathrm{nM} \mathrm{BSCaM}_{\mathrm{IQ}}$ in the presence of $20 \mu \mathrm{M} \mathrm{CaM}$ (B) The fractional fluorescence response of $5 \mu \mathrm{M}$ BSCaM $\mathrm{IQ}_{\mathrm{Q}}$ in the presence of $1 \mu \mathrm{M} \mathrm{CaM}(\boldsymbol{\square})$, and the fractional response of a solution of $1 \mu \mathrm{M}$ ECFP-CaM and $5 \mu \mathrm{M}$ EYFP-neuromodulin $(\Delta)$. Because FRET increases when this complex is formed, the fractional response in this case defined as $(\mathrm{F}$ $\left.-\mathrm{F}_{\min }\right) /\left(\mathrm{F}_{\max }-\mathrm{F}_{\min }\right)$. The curves in both panels were calculated as described under "Materials and Methods" according to the scheme depicted in Fig. 7. The $\mathrm{F}_{\min } / \mathrm{F}_{\max }$ values used to generate for these curves were adjusted slightly to achieve the fits shown. All adjusted values were within $3 \%$ of the mean values given in Table 1 . 


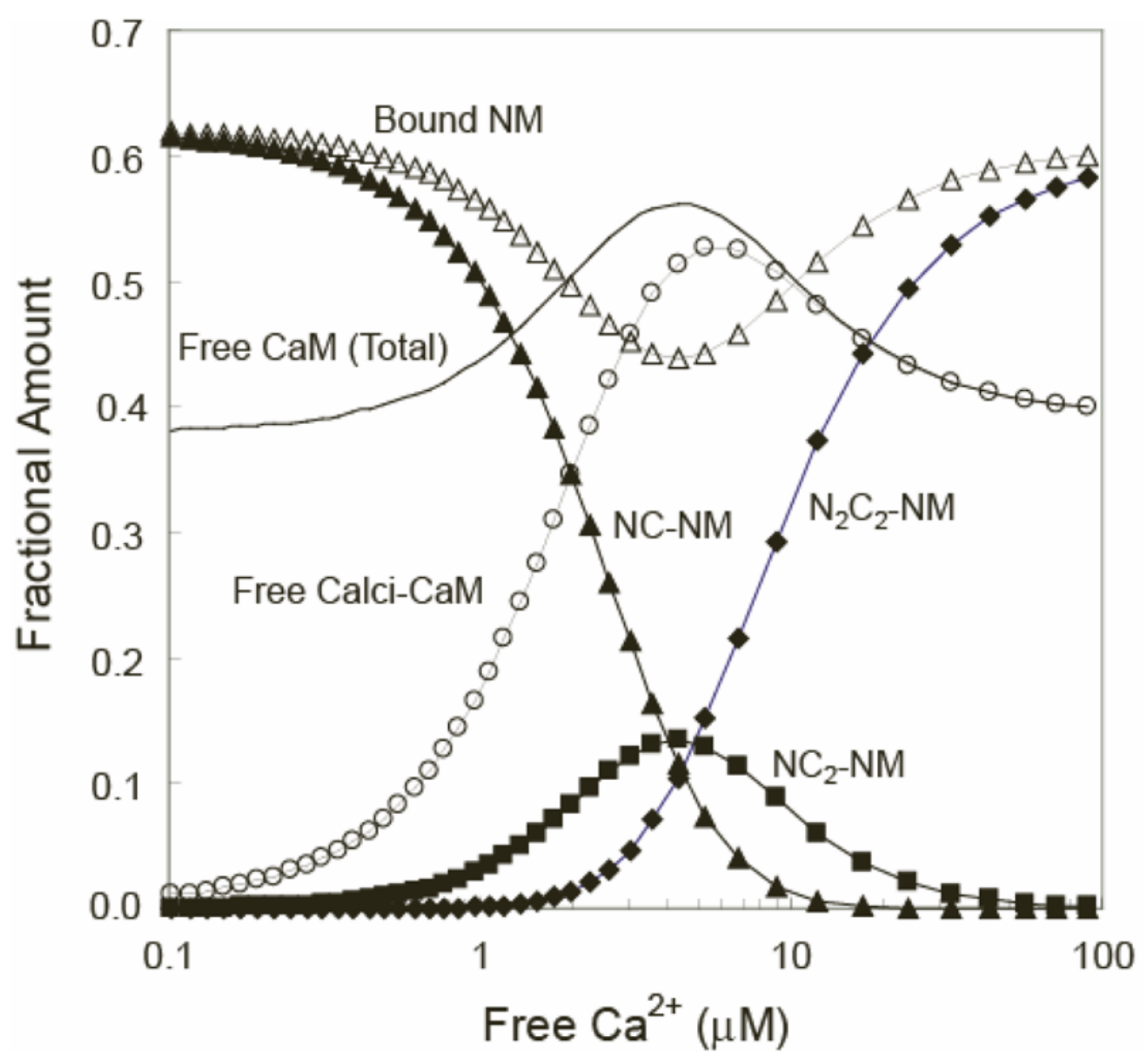

Fig. 9. Various species produced in a solution of neuromodulin (NM) and CaM as a function of the free $\mathrm{Ca}^{2+}$ concentration

Calculations were performed as described under "Materials and Methods" using CaM and NM concentrations of $10 \mu \mathrm{M}$ based on the scheme depicted in Fig. 7. All calculated concentrations are expressed relative to the total $\mathrm{CaM}$ concentration. Curves correspond with the relative concentrations of bound NM $(\Delta)$, total free CaM (no symbol), free calci-CaM $(\circ)$, NCCaMNM complex $(\boldsymbol{\Delta}), \mathrm{NC}_{2} \mathrm{CaM}-\mathrm{NM}$ complex $(\boldsymbol{\nabla})$, and $\mathrm{N}_{2} \mathrm{C}_{2} \mathrm{CaM}-\mathrm{NM}$ complex $(\boldsymbol{\nabla})$. Calci-CaM refers to the total of all free $\mathrm{Ca}^{2+}$-liganded $\mathrm{CaM}$ species, which primarily consist of $\mathrm{NC}_{2} \mathrm{CaM}$ and $\mathrm{N}_{2} \mathrm{C}_{2}$-CaM. Otherwise, the nomenclature for the various $\mathrm{Ca}^{2+}$-liganded species of $\mathrm{CaM}$ is given in the legend to Table 1. 


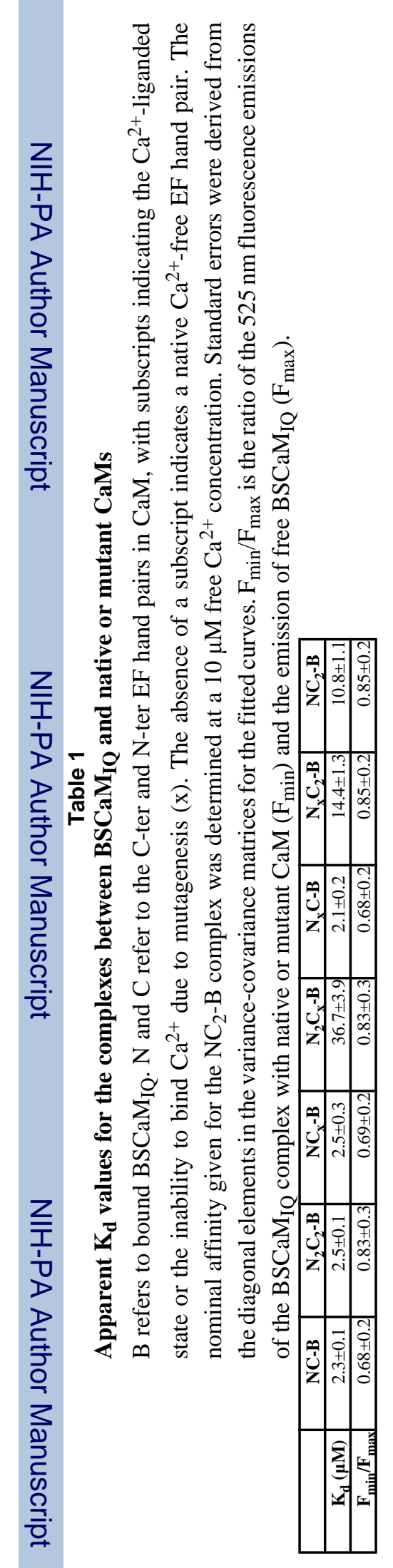

Biochemistry. Author manuscript; available in PMC 2008 September 8. 


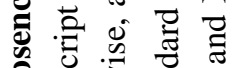

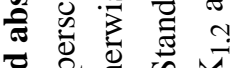

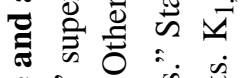
近它客离

\

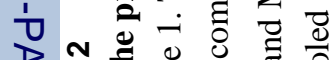

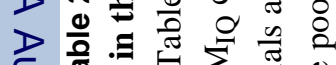

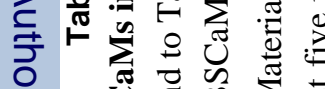

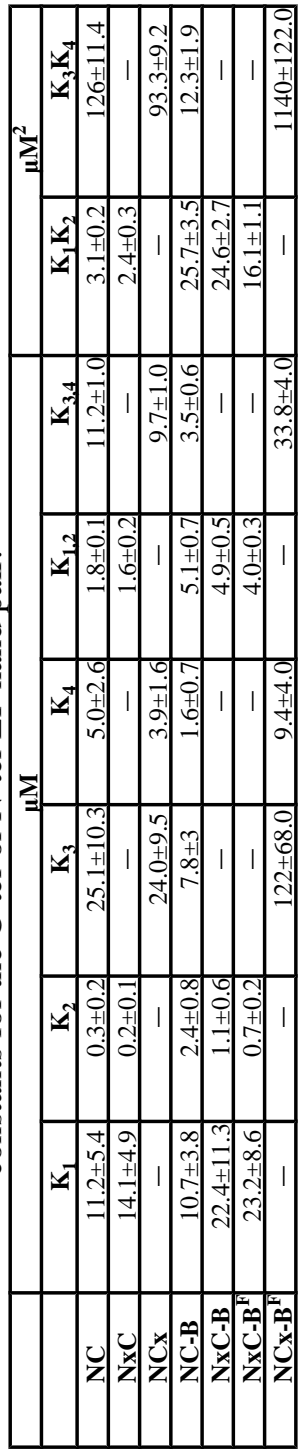




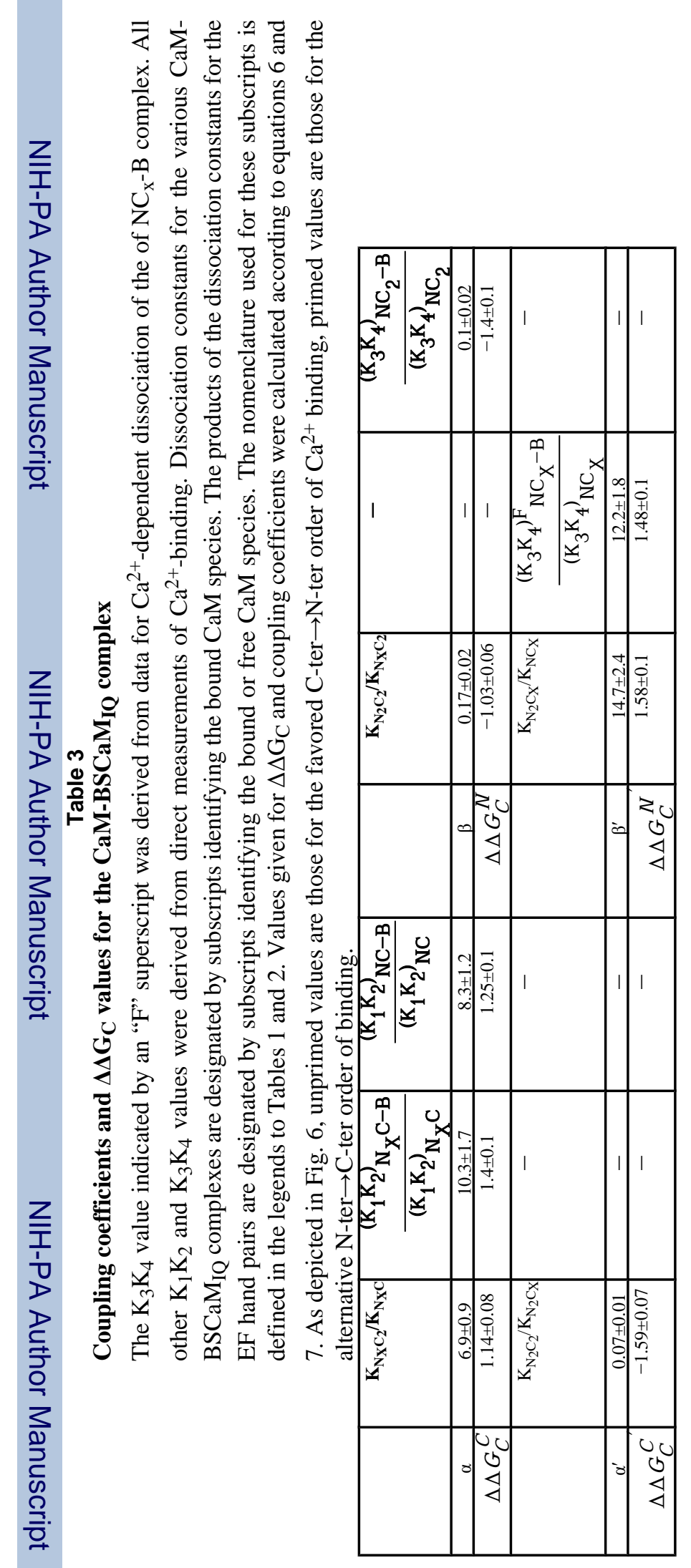

Biochemistry. Author manuscript; available in PMC 2008 September 8. 